\title{
Cellular and humoral immune responses against the Plasmodium vivax MSP-1 19 malaria vaccine candidate in individuals living in an endemic area in north-eastern Amazon region of Brazil
}

Evelyn KP Riccio ${ }^{1,2}$, Paulo RR Totino 1,2, Lilian R Pratt-Riccio 1,2, Vitor Ennes-Vidal ${ }^{3}$, Irene S Soares ${ }^{4}$, Maurício Martins Rodrigues ${ }^{5}$, José Maria de Souza ${ }^{6}$, Cláudio Tadeu Daniel-Ribeiro ${ }^{1,2}$ and Maria de Fátima Ferreira-da-Cruz ${ }^{1,2^{*}}$

\begin{abstract}
Background: Plasmodium vivax merozoite surface protein-1 (MSP-1) is an antigen considered to be one of the leading malaria vaccine candidates. PVMSP-1 is highly immunogenic and evidences suggest that it is target for protective immunity against asexual blood stages of malaria parasites. Thus, this study aims to evaluate the acquired cellular and antibody immune responses against PvMSP-1 in individuals naturally exposed to malaria infections in a malaria-endemic area in the north-eastern Amazon region of Brazil.

Methods: The study was carried out in Paragominas, Pará State, in the Brazilian Amazon. Blood samples were collected from 35 individuals with uncomplicated malaria. Peripheral blood mononuclear cells were isolated and the cellular proliferation and activation was analysed in presence of $19 \mathrm{kDa}$ fragment of MSP-1 (PVMSP-1 ${ }_{19}$ ) and Plasmodium falciparum PSS1 crude antigen. Antibodies $\lg E$, IgM, IgG and $\lg G$ subclass and the levels of TNF, IFN- $\gamma$ and IL-10 were measured by enzyme-linked immunosorbent assay.

Results: The prevalence of activated $\mathrm{CD} 4^{+}$was greater than $\mathrm{CD} 8^{+} \mathrm{T}$ cells, in both ex-vivo and in $96 \mathrm{~h}$ culture in presence of PvMSP-1 19 and PSS1 antigen. A low proliferative response against PvMSP- $1_{19}$ and PSS1 crude antigen after $96 \mathrm{~h}$ culture was observed. High plasmatic levels of IFN- $\gamma$ and IL-10 as well as lower TNF levels were also detected in malaria patients. However, in the $96 \mathrm{~h}$ supernatant culture, the dynamics of cytokine responses differed from those depicted on plasma assays; in presence of PVMSP-1 ${ }_{19}$ stimulus, higher levels of TNF were noted in supernatant 96 h culture of malaria patient's cells while low levels of IFN- $\gamma$ and IL-10 were verified. High frequency of malaria patients presenting antibodies against PvMSP-1 ${ }_{19}$ was evidenced, regardless class or IgG subclass. PvMSP-1 19 -induced antibodies were predominantly on non-cytophilic subclasses.

Conclusions: The results presented here shows that PvMSP-1 ${ }_{19}$ was able to induce a high cellular activation, leading to production of TNF and emphasizes the high immunogenicity of PvMSP-1 ${ }_{19}$ in naturally exposed individuals and, therefore, its potential as a malaria vaccine candidate.
\end{abstract}

Keywords: Malaria, Plasmodium vivax, MSP- ${ }_{19}$, Cellular response, Antibodies

\footnotetext{
* Correspondence: mffcruz@ioc.fiocruz.br

'Laboratório de Pesquisas em Malária, Instituto Oswaldo Cruz, Fiocruz,

Avenida Brasil 4365, Manguinhos, Rio de Janeiro, RJ, BrazilCEP: 21040-900

${ }^{2}$ Centro de Pesquisa, Diagnóstico e Treinamento em Malária (CPD-Mal),

Fiocruz, Reference Center for Malaria in the Extra-Amazonian Region for the

Secretary for Health Surveillance from the Ministry of Health, Rio de Janeiro,

RJ, Brazil

Full list of author information is available at the end of the article
} 


\section{Background}

Malaria remains a serious public health problem causing high levels of morbidity and mortality in malariaendemic regions. There were an estimated 219 million cases of malaria and 660,000 deaths in 2010 [1]. Among the five Plasmodium species responsible for natural infection of human, Plasmodium vivax has the widest geographical distribution, being the second leading cause of malaria [1]. Although usually considered a benign infection, severe $P$. vivax malaria cases have been reported worldwide [2-10]. In Brazil, $P$. vivax accounts for around $85 \%$ of clinical cases [11].

Since an effective malaria vaccine has long been envisaged as a potential tool for malaria control, two important points for its development are the identification of antigens that elicit the relevant immunological machinery and the correlation between the resulting immune system products and the clinical and/or parasitological protection induced. In this context, several antigens are being evaluated in clinical trials. To date, one candidate vaccine is currently being assessed in Phase 3 clinical trials and approximately 20 others in Phase 1 or Phase 2 trials [1]. Among these antigens, $P$. vivax merozoite surface protein-1 (PvMSP-1) is a promising candidate.

MSP-1 is the most abundant and best-studied bloodstage antigen [12]. MSP-1 is a $190-230 \mathrm{kDa}$ protein present in almost all Plasmodium species, being synthesized in a precursor form during schizogony. Posttranslational proteolytic processing of the MSP-1 precursor molecule generates different fragments $(83,28-30$, $38-45$ and $42 \mathrm{kDa}$ ). The $42 \mathrm{kDa}$ fragment is processed to a $33 \mathrm{kDa}$ and a $19 \mathrm{kDa}$ fragments, leaving a membrane-anchored $19 \mathrm{kDa}$ fragment $\left(\mathrm{MSP}-1_{19}\right)$ on the parasite surface after its internalization in the erythrocyte [13-15].

The potential of PvMSP-1 as a vaccine candidate is based on previous studies that reported that it is highly immunogenic under natural conditions of exposure [16-24] and that it could partially protect Saimiri monkeys [25]. Several studies have provided evidences that MSP- $1_{19}$ is a target for protective immunity against asexual blood stages of malaria parasites [26-28]. This protective immunity has been shown to correlate with levels of anti- MSP- $1_{19}$ antibodies and it is also dependent of CD4 T cells $[27,29,30]$.

Given the cumulative data supporting the potential of PvMSP-1 as a malaria vaccine, and the substantial data generated through studies in human indicating that both humoral and cellular immune responses are needed to protect against malaria, the present study aims to evaluate the acquired cellular and antibody immune responses against PvMSP- $1_{19}$ in individuals naturally exposed to $P$. vivax or Plasmodium falciparum infections in a malaria-endemic area in the north-eastern Amazon region of Brazil.

\section{Methods}

Study setting, participants, and blood collection

The study was carried out in Paragominas (47 36' 09.63“ W, $03^{\circ} 12^{\prime}$ 11.02” S), Pará State, in the Brazilian Amazon. The samples were collected in 2004. The individuals were studied by means of a questionnaire, whereby all relevant information, including personal and epidemiological data, were collected.

Written informed consent was obtained from all volunteer donors and $10 \mathrm{ml}$ of venous blood samples were drawn in Vacutainer EDTA tubes (Becton Dickinson, Oxnard, CA) from 35 individuals with uncomplicated malaria at the Hospital Municipal de Paragominas (HMP). Blood samples from 17 individuals living in Paragominas but with no history of current or previous malaria episodes were included in the study as noninfected control individuals. Blood collection was performed at the day of diagnosis and patients were treated, according to the Brazilian Ministry of Health standards for malaria therapy, immediately after blood sample collection.

Thin and thick blood smears were examined for identification of malaria parasite and determination of parasitaemia by two expert malaria microscopists from HMP and from the Laboratory of Malaria Research (Fiocruz, Rio de Janeiro, Brazil) which is a reference centre in malaria diagnosis for the Brazilian Ministry of Health. Blood smears from all subjects were stained with Giemsa and examined under 1,000-fold magnification. Parasitaemia was determined by counting parasites in reference to 200 white blood cells in thick blood films, and the number of the blood parasites per millilitre was calculated.

Nonendemic control blood samples from five individuals of the laboratory staff (Rio de Janeiro, Brazil) who had neither history of malaria nor contact with a malaria transmission area, were included in the study as 'Rio controls'. The study was reviewed and approved by the Fundação Oswaldo Cruz and Instituto Evandro Chagas Ethical Committees.

\section{Isolation of peripheral blood mononuclear cells (PBMC)}

The blood samples were centrifuged for $10 \mathrm{~min}, 400 \times g$ and, after removal of plasma, the corresponding volume of RPMI-1640 (Sigma, St. Louis, Mo) medium containing $15 \mathrm{mM}$ glutamin (Sigma), $10 \mathrm{mM}$ Hepes (Sigma), $200 \mathrm{U} / \mathrm{ml}$ penicillin (Gibco), $200 \mu \mathrm{g} / \mathrm{ml}$ streptomycin (Gibco), $3 \mathrm{mg} / \mathrm{ml}$ gentamicyn (Sigma) and $2 \mathrm{~g} / \mathrm{L}$ sodium bicarbonate (Sigma) was added. Subsequently, PBMC were isolated by density gradient centrifugation (FycollHypaque) and were washed twice in serum-free RPMI 1640 medium (Sigma). The cells were cryopreserved according to the method described by Ichino and Ishikawa [31]. Briefly, cells were resuspended in $4^{\circ} \mathrm{C}$ 
RPMI-1640 supplemented with 40\% foetal calf serum with an equal volume of cold RPMI-1640 containing $20 \%$ dimethyl sulfoxide (Sigma) and transferred to cryotubes that were immersed in a cold ethanol bath $\left(4^{\circ} \mathrm{C}\right)$ and placed in a $-70^{\circ} \mathrm{C}$ freezer for at least $12 \mathrm{~h}$. The samples were then transferred to a liquid nitrogen storage tank. After freezing for up to 30 days, the cells were thawed and the viability was assessed using trypan blue staining. The thawing of PBMC was performed by the immersion of cryotubes in a $37^{\circ} \mathrm{C}$ water-bath, followed by two washes in RPMI-1640 medium $\left(4^{\circ} \mathrm{C}\right)$ for $10 \mathrm{~min}, 400 \times g$.

\section{Recovery and viability after cryopreservation}

The number of viable cells was verified immediately after thawing of PBMC (ex-vivo) by cytometry flow using 7-aminoactinomycin D (7-AAD). This rapid and sensitive method allows the discrimination of live cells from apoptotic or necrotic cells [32]. The cells were then incubated for $20 \mathrm{~min}$ at $4^{\circ} \mathrm{C}$ with $300 \mu \mathrm{l}$ of $10 \mu \mathrm{g} / \mathrm{ml}$ of 7-AAD (Sigma) in phosphate-buffered saline (PBS) containing $2 \%$ foetal calf serum (Hyclone) and $0.1 \%$ sodium azide. After incubation, $300 \mu \mathrm{l}$ of $2 \%$ paraformaldehyde were added to the samples. Labelled samples were analysed in a FACSCalibur (Becton Dickinson and Company, Franklin Lakes, USA) and red fluorescence from 7-AAD was filtered through a $675 \mathrm{~nm}$ long pass filter. Approximately 10,000 events were analysed for each sample.

\section{Plasmodium falciparum crude extracts preparation}

The PSS1 P. falciparum strain (Peixoto de Azevedo, Brazil) was cultivated in vitro according to the method described by Trager and Jensen [33]. The P. falciparum crude extract was obtained from infected erythrocytes with parasitaemia above 6\%. Parasitized erythrocytes with a predominance of schizonts were washed three times with PBS. The lysis of infected erythrocytes was done by addition of $0.1 \%$ saponin and gentle shaking for $15 \mathrm{~min}$. The lysates were ultrasonicated in the presence of $1 \mathrm{mM}$ phenylmethylsulfonyl fluoride and centrifuged $7,000 \times g$ for $15 \mathrm{~min}$ at $4^{\circ} \mathrm{C}$ in order to eliminate the cellular debris.

\section{Cellular proliferation assay}

Cellular proliferation was analysed by using the vital staining carboxyfluorescein diacetate succinimidyl ester (CFSE, Molecular Probes). The PBMC were ressuspended in $1 \mathrm{ml}$ of PBS plus $0,01 \%$ bovine serum albumin (BSA, Sigma) at $37^{\circ} \mathrm{C}$. Two microlitres of a stock solution of CFSE $(5 \mu \mathrm{M})$ were added in $1 \mathrm{ml}$ of cellular suspension containing up to $1 \times 10^{6}$ cells $/ \mathrm{ml}$. The samples were then incubated for $10 \mathrm{~min}$ at $37^{\circ} \mathrm{C}$. Five millilitres of RPMI-1640 at $4^{\circ} \mathrm{C}$ were added and the samples were incubated for $5 \mathrm{~min}$ in ice-bath. After incubation, the cells were washed three times with RPMI1640 and then ressuspended with $1 \mathrm{ml}$ RPMI-1640 (Sigma) medium containing $15 \mathrm{mM}$ glutamin (Sigma), $10 \mathrm{mM}$ Hepes (Sigma), $200 \mathrm{U} / \mathrm{ml}$ penicillin (Gibco), $200 \mu \mathrm{g} / \mathrm{ml}$ streptomycin (Gibco), $3 \mathrm{mg} / \mathrm{ml}$ gentamicin (Sigma), 3,7 g/l sodium bicarbonate (Isofar), $100 \mathrm{mM}$ piruvate (Sigma),14 mM $\beta$-mercaptoetanol (Sigma) and $10 \%$ of inactivated foetal calf serum (FCS) (complete medium). The PBMC were distributed $2.5 \times 10^{5}$ cells/ well in triplicate in 96-well flat-bottom microtiter plates (Falcon) in final volume of $200 \mu \mathrm{l}$ of complete medium alone or in the presence of $5 \mu \mathrm{g} / \mathrm{ml}$ phytohaemagglutinin (PHA), $10 \mu \mathrm{g} / \mathrm{ml} \mathrm{P.} \mathrm{falciparum} \mathrm{crude} \mathrm{extract} \mathrm{or}$ PvMSP-1 $_{19}$ (kindly provided by Dr. Mauricio Rodrigues and Dra. Irene Soares) and, then, incubated at $37^{\circ} \mathrm{C}$ in $5 \%$ $\mathrm{CO}_{2}$ for 48 or $96 \mathrm{~h}$. After culture, the cellular proliferation was analysed using a FACSCalibur flow cytometer.

\section{Determination of cellular activation}

The determination of cellular activation was done by using monoclonal antibodies against CD25, CD4, CD8 and CD21. The protocol consisted of the addition of 5-10 $\mu \mathrm{l}$ of the optimal antibody dilution to $5 \times 10^{5}$ cells in $50 \mu \mathrm{l}$ PBS containing $2 \%$ foetal calf serum and $0.1 \%$ sodium azide (azide PBS), followed by incubation for 20-30 min at $4^{\circ} \mathrm{C}$. After two washes with PBS, the cells were resuspended in $200 \mu \mathrm{l}$ of azide PBS. The cells were then fixed with a $2 \%$ paraformaldehyde solution and maintained in the dark until the analysis in a FACSCalibur flow cytometer. At least 10,000 events were analysed.

Enzyme-linked immunosorbent assay (ELISA) for PvMSP-1 19 Microtiter 96-well plates (Nunc Maxisorp) were coated overnight at room temperature with $50 \mu \mathrm{l}$ of $4 \mu \mathrm{g} / \mathrm{ml}$ PvMSP- $1_{19}$ protein in $0,05 \mathrm{M}$ carbonate-bicarbonate buffer, pH 9.6. Plates were washed three times with PBS containing $0,05 \%$ Tween 20 (PBS/T20). Uncoated sites were blocked for $2 \mathrm{~h}$ at room temperature with $200 \mu \mathrm{l}$ of PBS/T20 containing 5\% powdered-milk. After incubation, $50 \mu \mathrm{l}$ of the plasma sample diluted 1:50 in powdered-milk-containing PBS/T20 were added and the plates were incubated for $2 \mathrm{~h}$ at room temperature.

Plates were washed thrice with PBS/T20 and 50 $\mu \mathrm{l} /$ well of mouse anti-human IgE, IgM, IgG or IgG subclass (Sigma) peroxidase conjugated, in optimal antibody dilution in PBS, was added. Plates were incubated for $1 \mathrm{~h}$ at $37^{\circ} \mathrm{C}$. After washing the plates with PBS/T20, $50 \mu \mathrm{L}$ of a solution containing $1 \mathrm{mg} / \mathrm{ml}$ of OPD (Sigma) and $15 \mu \mathrm{l}$ 
of $30 \% \mathrm{H}_{2} \mathrm{O}_{2}$ in citrate-phosphate buffer pH 5.0 were added. After incubation for 10-15 $\mathrm{min}$ at room temperature in the dark, the reaction was stopped with $50 \mu \mathrm{l} /$ well of $\mathrm{H}_{2} \mathrm{SO}_{4}$. The absorbance was read at $405 \mathrm{~nm}$ in a spectrophotometer (Spectra Max 250; Molecular Devices, Sunnyvale, CA).

The cut-off value was determined as the mean optical density (OD) plus two standard deviations from controls that never visited malaria endemic areas. To standardize the OD data obtained in different experiments, OD index was calculated for each immunoglobulin determination as the ratio of the observed OD to the cut-off values. A sample with an OD index $>1.0$ was considered positive.

\section{Assays for cytokine detection}

The cytokine levels in plasma and supernatant cultures samples were measured by ELISA using reagents from BD Biosciences Pharmingen, USA. Briefly, $100 \mu \mathrm{l}$ of the capture monoclonal anti-human TNF, IFN- $\gamma$ or IL-10 antibodies in optimal dilutions were used to coat 96-well plates for $14 \mathrm{~h}$ at $4^{\circ} \mathrm{C}$. After washing and blocking, $100 \mu \mathrm{l}$ of plasma samples diluted 1:2 or supernatant of the cultures were added to duplicated wells and incubated for $24 \mathrm{~h}$ at $4^{\circ} \mathrm{C}$. After the samples were washed, biotinylated anti-human cytokine were added and the plates were incubated for $1 \mathrm{~h}$ at room temperature. The presence of bound antibodies was detected using streptavidinperoxidase (Sigma Chemical Co., St Louis, USA) for $30 \mathrm{~min}$ at room temperature, followed by the addition of 2,2' -azinobis (3-ethylbenzthiazolinesulfonic acid) (ABTS; Sigma Chemical Co., St Louis, USA) and 30\% hydrogen peroxide (Merck, Darmstadt, Germany) as the substrate. The reaction was stopped with $20 \%$ sodium dodecyl sulphate (Merck, Darmstadt, Germany), and the absorbance was read at $405 \mathrm{~nm}$ in a spectrophotometer (Spectra Max 250; Molecular Devices, Sunnyvale, CA). A standard curve was constructed for each cytokine by using different dilutions of human recombinant cytokines.

\section{Statistical analysis}

For unpaired analyses, the nonparametric Mann-Whitney test was used to determine the significance of differences in plasmatic concentrations of cytokines between patients with acute malaria infection and control individuals and also among patient antibody responses. The Spearman rank correlation coefficient test was used to evaluate the correlation of epidemiological and immunological data. Student's t-test was used to analyse differences in mean values, and chi-square analysis was applied to compare the prevalence of positive responses. Spearman rank coefficient test was also used to analyse the variable correlations. $p$ values less than 0.05 were considered significant.

\section{Results}

\section{Characteristics of study groups}

Blood collection was performed at the day of diagnosis, before malaria treatment. Patients sought health care at Brazilian health services $6.8 \pm 6.9$ days after onset of symptoms. Throughout the study period, a total of 35 samples were collected from uncomplicated malaria cases (malaria group) with $P$. falciparum $(\mathrm{n}=12)$ or P. $\operatorname{vivax}(\mathrm{n}=23)$ infection and from individuals $(\mathrm{n}=17)$ living also in downtown Paragominas but with no history of current or previous malaria episodes (control group).

The malaria group consisted of 6 female and 29 men with age ranging from 12 to 67 years old $(31 \pm 14$ years old). Twenty six percent denied prior malaria infection and $64 \%$ reported $4.7 \pm 6.0$ previous malaria episodes during life. The individuals from the malaria group claimed living in malaria endemic area for $19 \pm 13$ years. All of them presented, at time of blood sampling, symptoms and positive thick blood smears, with a parasitaemia ranging from 50 to $3,000(1,213 \pm 1,088)$ parasites/ $\mu \mathrm{l}$ for $P$. falciparum and 75 to $5,000(1,640 \pm 1,220)$ parasites/ $\mu$ l for $P$. vivax.

Individuals from the control group claimed living in malaria endemic area for $18 \pm 13$ years and corresponded to 10 women and seven men with average age of $35 \pm$ 7 years. All individuals were negative for malaria parasites as assessed by thick blood films.

\section{Viability of peripheral blood mononuclear cells (PBMC) after thawing}

The viability of mononuclear cells after thawing was analysed and the percentages observed in malaria patients $(78.1 \pm 12.5 \%)$ were similar to those found in healthy individual $(78.7 \pm 19.6 \%)$. Likewise, no difference was observed when comparing the viability of PBMC from $P$. falciparum and $P$. vivax malaria patients.

\section{Phenotypic analysis of ex-vivo PBMC samples}

The phenotypic analysis of ex-vivo PBMC revealed that, as expected, $\mathrm{CD} 4^{+} \mathrm{T}$ cells were found more frequently than $\mathrm{CD}^{+}$and $\mathrm{CD}^{+} 0^{+}$cells, in both malaria and control individuals (Table 1). No difference was observed when

Table 1 Ex-vivo analysis of $\mathrm{CD4} 4^{+}, \mathrm{CD8}^{+} \mathrm{T}$ cells and $\mathrm{B}$ cells $\left(\mathrm{CD}^{+} \mathrm{O}^{+}\right.$) from malaria patients and control individuals

\begin{tabular}{lcc}
\hline Cells & Malaria & Controls \\
\hline $\mathrm{CD}^{+}$ & $45,6 \pm 15,7$ & $45,3 \pm 12,4$ \\
$\mathrm{CD}^{+}$ & $23,4 \pm 7,9$ & $24 \pm 10,3$ \\
$\mathrm{CD}^{+} \mathrm{O}^{+}$ & $20,1 \pm 22,9$ & $10,7 \pm 9,6$
\end{tabular}

(Mean \pm standard deviation). 
comparing the frequency of $\mathrm{CD} 4^{+}, \mathrm{CD}^{+}$and $\mathrm{CD} 20^{+}$ cells between malaria and control individuals.

Cellular activation ex-vivo and after 96 hours culture The cellular activation was analysed by the expression of interleukin-2 receptor (IL-2R), using an anti-CD25 monoclonal antibody.

In ex-vivo analysis, PBMC from malaria individuals presented higher levels of cellular activation (27.2 \pm $14.2 \%)$ than control individuals $(18.2 \pm 11.9 \%)$. No difference in cellular activation was observed when comparing P. falciparum $(24.7 \pm 16.8)$ and P. vivax $(31.4 \pm 18.3)$ infected individuals (Figure 1). In malaria individuals, $\mathrm{CD}^{+}{ }^{+} \mathrm{T}$ cells were more activated $(16.1 \pm 12.2 \%)$ than CD8+ T cells $(3.2 \pm 3.3 \%)$. The same result was observed when comparing $P$. vivax $\left(\mathrm{CD}^{+}: 17.6 \pm 13.9 ; \mathrm{CD}^{+}\right.$: $3.6 \pm 3.7)$ and $P$. falciparum $\left(\mathrm{CD}^{+}: 13.6 \pm 8.2\right.$; $\mathrm{CD}^{+}$:

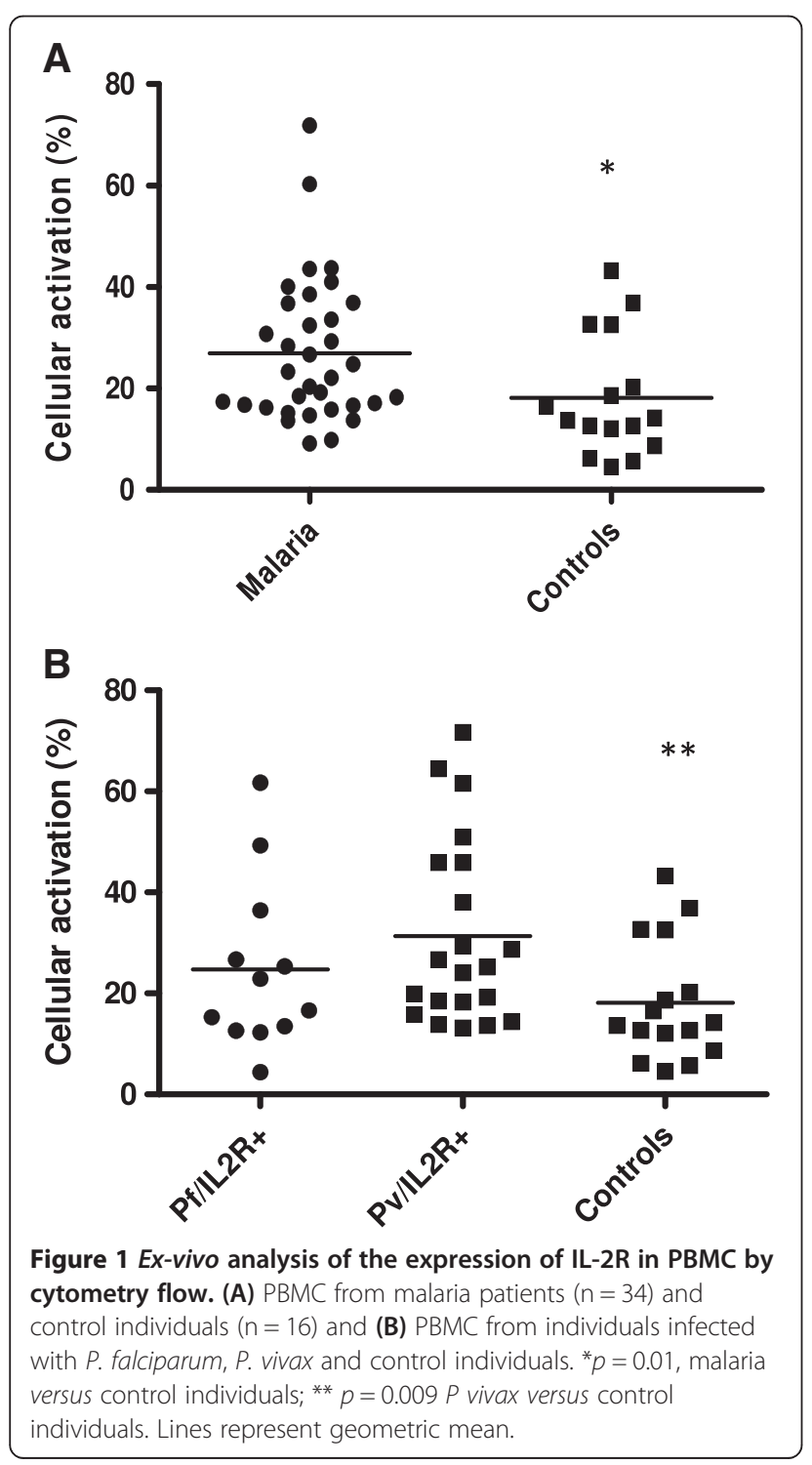

$2.3 \pm 2$ ) infected individuals. However, no difference was observed in the levels of cellular activation of $\mathrm{CD}^{+}$or $\mathrm{CD}^{+}$between $P$. falciparum and $P$. vivax infected individuals (Figure 2).

In $96 \mathrm{~h}$ culture in the presence of PvMSP- $1_{19}$ (malaria, $50.9 \pm 23.6 \%$; controls $15.7 \pm 26.8$ ) or PSS1 crude antigen (malaria, $47.2 \pm 23.4 \%$; controls $11.6 \pm 23.9 \%$ ), higher levels of cellular activation were observed in malaria group than in controls individuals. The same result was observed when comparing P. vivax (PvMSP1 $1948.9 \pm$ 24.3; PSS1 $42.7 \pm 23.5$ ) and P. falciparum (PvMSP1 19 $54.6 \pm 23.5$; PSS1 $55 \pm 22.6$ ) infected individuals. However,

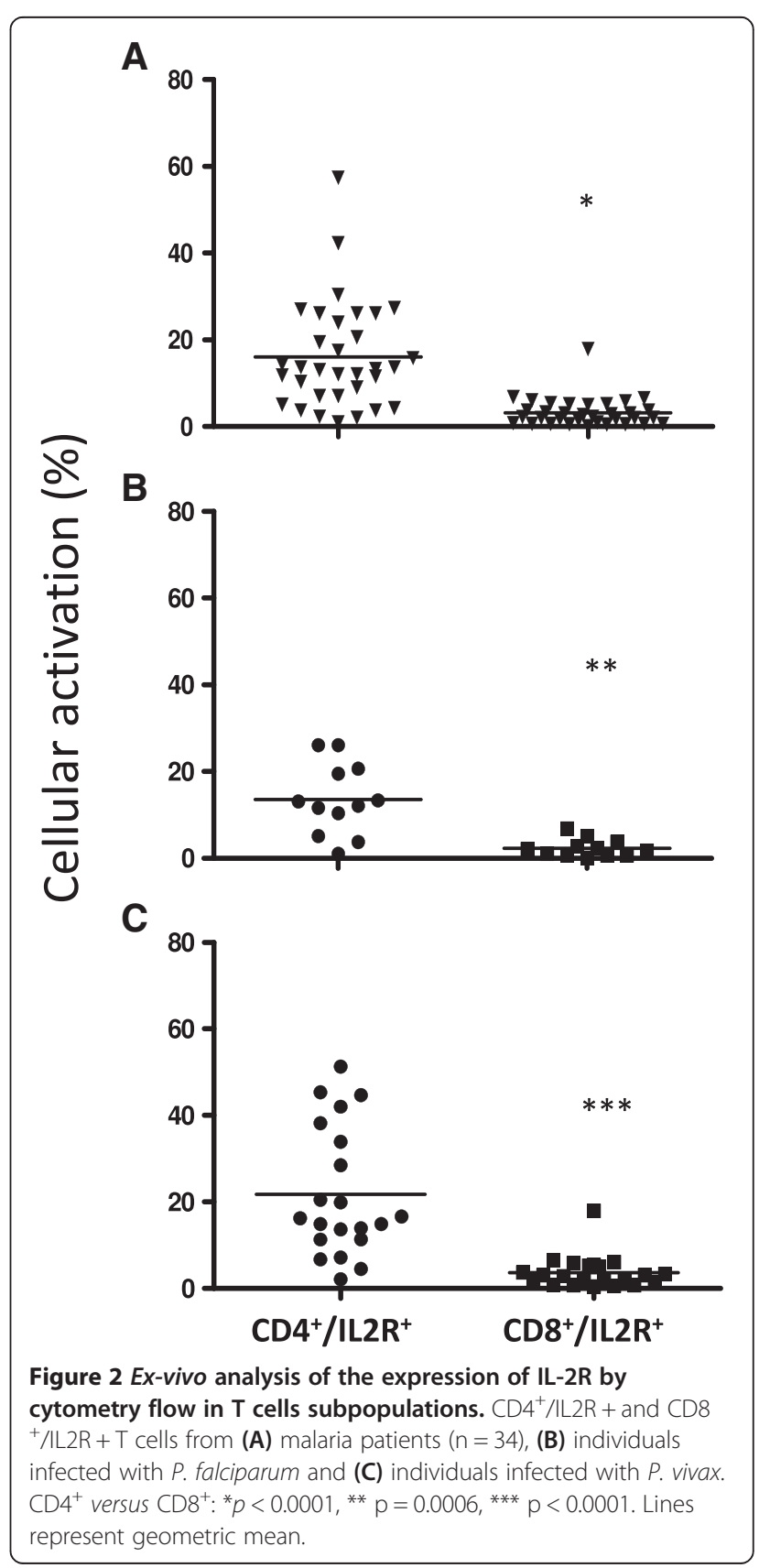


no difference was observed in the levels of cellular activation between $P$. falciparum and $P$. vivax infected individuals (Figure 3 ). These activated cells were mainly CD4+ T cells (Figure 4).

\section{Proliferative response}

After $96 \mathrm{~h}$ of culture, no difference was observed when comparing different stimuli in malaria individuals. Also, in control individuals, no proliferative response was observed when cells were cultivated without stimulus or in presence of both PvMSP-1 19 and PSS1 crude antigen. However, in presence of PHA, the proliferative response was two fold higher in control individuals than that observed in malaria patients (Figure 5).

\section{Cytokine profile}

\section{Plasmatic cytokine levels}

Higher plasmatic levels of IFN- $\gamma$ and IL-10 as well as lower TNF levels were observed in both malaria and

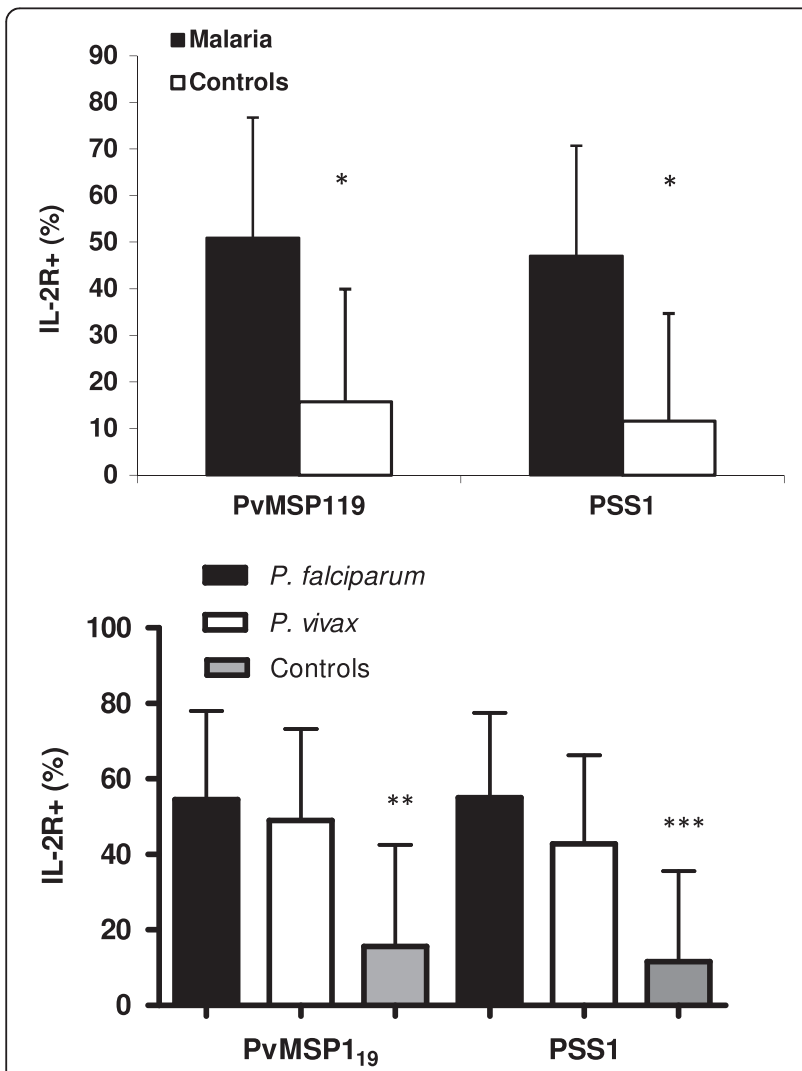

Figure 3 Analysis of cellular activation by the expression of IL-2R after $96 \mathrm{~h}$ culture in presence of PvMSP-1 ${ }_{19}$ and PSS1 crude antigen by cytometry flow. (A) PBMC from malaria patients $(n=35)$ and control individuals $(n=17)$ and $(B)$ PBMC from individuals infected with $P$. falciparum, $P$. vivax and control individuals. ${ }^{*} p=0.001$ for $\mathrm{PVMSP}_{19}$ and $p=0.0003$ for PSS1, malaria versus control individuals; ** $p=0.009$ for $P$. falciparum versus controls and $p=0.003$ for $P$. vivax versus controls; ${ }^{* * *} p=0.004$ for $P$. falciparum versus controls and $p=0.001$ for $P$. vivax versus controls.
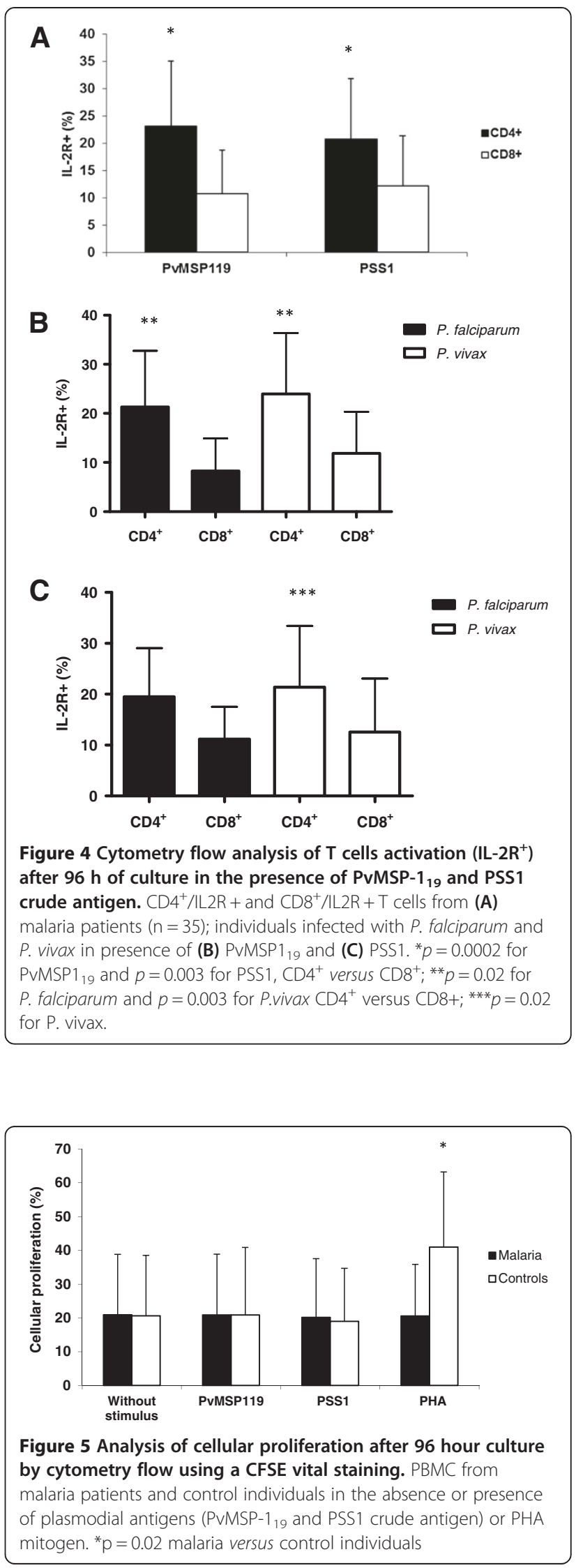
individuals infected with $P$. vivax than control individuals (Figure 6). No difference was observed between TNF and IL-10 levels when comparing P. falciparum- or $P$. vivax-infected individuals. However, higher levels of IFN- $\gamma$ were noted in $P$. vivax- infected individuals $(p=0.03)$ (Figure 7).

In malaria patients, no correlation was observed between levels of plasmatic TNF or IFN and age, the number of previous malaria infection, time of residence in malaria endemic area, parasitaemia or the time elapsed between first symptoms and malaria diagnosis. However, a negative correlation was detected between plasmatic levels of IL-10 and the number of previous malaria infection $(p=0.0186 ; \mathrm{r}=-0.3958)$ in malaria individuals.

\section{Cytokine levels from culture supernatant of PBMC}

In the $96 \mathrm{~h}$ supernatant culture as represented in Figure 8, the dynamics of cytokine responses differed from those depicted in the study of the plasma samples. In presence of PvMSP-1 19 stimulus, higher levels of TNF were observed in supernatant $96 \mathrm{~h}$ culture of malaria individuals' cells when comparing with both PSS1 crude antigen $(P=0,03)$ or without stimulus $(P=0,0006)$. No statistical difference was observed between cytokines levels from supernatant cultures of $P$. falciparum- or $P$. vivax-infected patients. In malaria patients, a positive correlation was observed between the levels of TNF obtained from supernatants of cultures stimulated with PvMSP- $1_{19}$ and the time of living in an endemic area $(P=0.001, \mathrm{r}=0.5196)$.

Regarding to IL-10, positive correlation was observed between the levels of this cytokine obtained from supernatants of PBMC stimulated with PvMSP1-19 $(P=0.0288$, $\mathrm{r}=0.3752)$ or with PSS1 $(P=0.033, \mathrm{r}=0.3661)$ and the time of residence in endemic area. Positive correlation was also observed between the number of previous malaria infection and the levels of IFN- $\gamma$ when PBMC were stimulated with PvMSP-1 $19(P=0.0004, \mathrm{r}=0.5704)$.

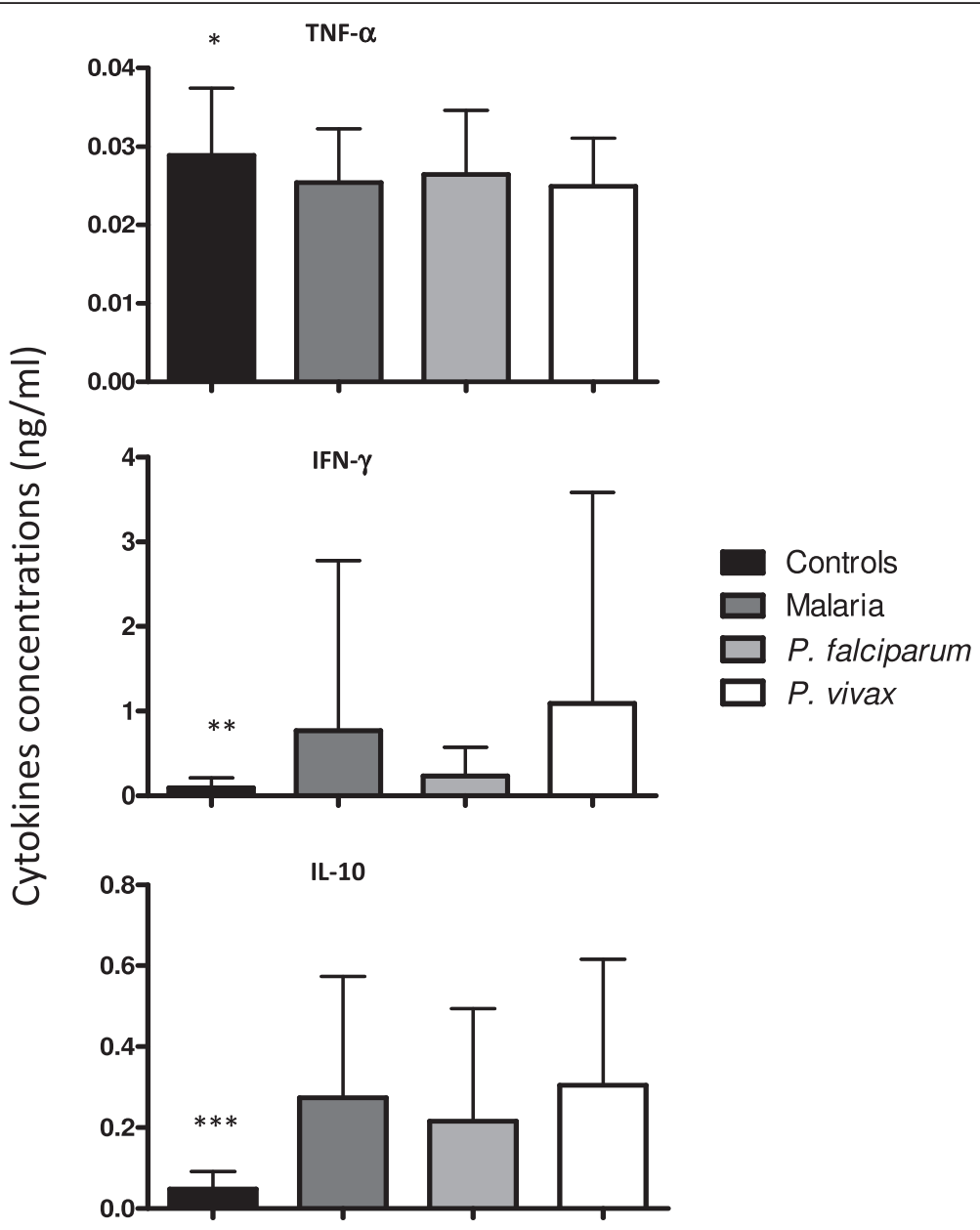

Figure 6 Plasmatic concentrations of cytokines evaluated by ELISA assays. Levels of TNF, IFN- $\gamma$ and IL-10 in plasma samples from control individuals, malaria patients, individuals infected with $P$. falciparum and individuals infected with $P$. vivax. ${ }^{*} P=0.01$ control versus malaria individuals and control versus P. vivax; ${ }^{* *} p=0.001$ for controls versus malaria; $p=0.0007$ control versus $P$. vivax; ${ }^{* * *} p<0.0001$ controls versus malaria and controls versus $P$. vivax; $P=0.001$ controls versus $P$. falciparum. 


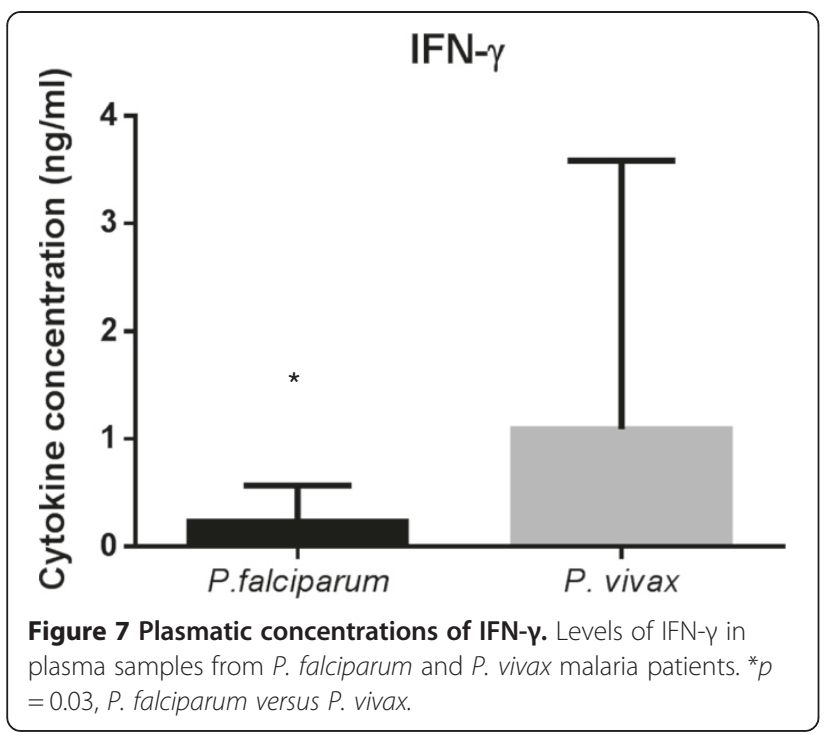

Humoral antibody response against PvMSP-1 19

High frequency $(30 / 35,86 \%)$ of malaria patients presenting antibodies to IgG, IgM, IgE type and IgG isotypes against PvMSP- $1_{19}$ was noticed. The frequencies of malaria patients presenting antibodies against PvMSP-1 19

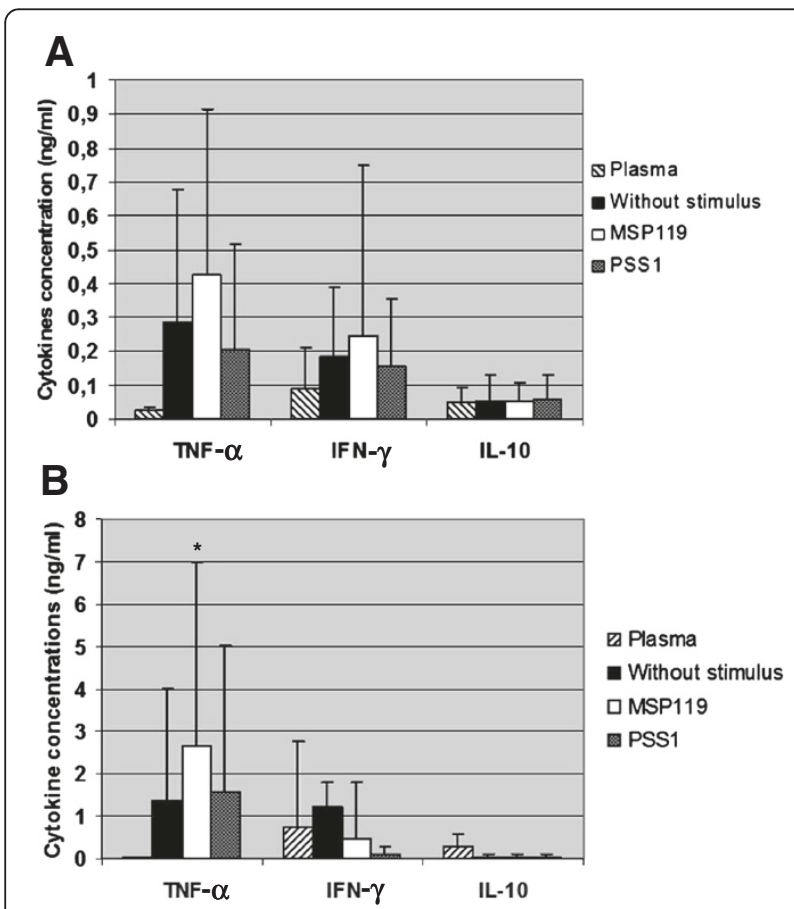

Figure 8 Analysis of cytokines concentrations in plasma and in supernatant of the cultures measured by ELISA. Levels of TNF, IFN- $\gamma$ and IL-10 in plasma samples and in supernatant of the PBMC cultures from (A) control individuals $(n=17)$ and $(\mathbf{B})$ malaria patients $(n=35) .{ }^{*} p=0.03$, PvMSP- $1_{19}$ versus PSS1; $p=0.0006$, PvMSP- $_{19}$ versus without stimulus. were $63 \%$ (22/35), 80\% (28/35) and 51\% (18/35) for IgG, IgM and IgE class, respectively (Figure 9). The percentage of patients presenting anti-PvMSP-1 19 IgM antibodies was higher than the frequency of patients presenting IgE antibodies $(p=0.02)$. Besides the IgM frequency, these patients presented also higher levels of anti PvMSP-1 19 IgM antibodies $(p=0.004)$ (Figure 10). No correlation between IgG or IgM antibodies and age, time of residence in malaria-endemic area, parasitaemia, number of previous malaria infection and time since last malaria infection was observed. However, the levels of IgE antibodies was inversely correlated with the number of previous malaria episodes $(p=0.01, \mathrm{r}=-0.4061)$. The frequency and the levels of IgG, IgM and IgE antibodies against PvMSP-1 19 were higher in patients infected with $P$. vivax than in patients infected with $P$. falciparum (Figures 11 and 12).

None of the 17 control individuals had detectable IgG, IgM or IgE antibodies against PvMSP1 19 or PSS1 crude antigen. The prevalences of IgG1, IgG2, IgG3 and IgG4 subclasses in IgG-positive malaria patients were, respectively, 64\% (14/22), 86\% (19/22), 14\% (3/22) e 91\% (20/22). PvMSP-1 19 -induced antibodies were predominantly of non-cytophilic subclasses (Figure 13). Anti-PvMSP-1 19 IgG3 antibodies were less prevalent than IgG1, IgG2 and IgG4 antibodies $(p=0.001$ IgG3 versus IgG1; $p<0.0001$ IgG3 versus IgG2; $p<0.0001$ IgG3 versus IgG4). The levels of anti-PvMSP-1 19 IgG4 antibodies were higher than the levels of IgG1, IgG2 and IgG3 antibodies ( $p=0.04$ IgG4 versus IgG1; $p=0.03$ IgG4 versus IgG2; $p=0.01$ IgG4 versus IgG3) (Figure 14). No correlation between IgG1, IgG2, IgG3 or IgG4 and age, time of residence in malaria-endemic area, parasitaemia, number of previous malaria infection and time elapsed after last malaria attack was observed. Also, no association was observed in the prevalence or levels of IgG1, IgG2, IgG3 and IgG4 antibodies against PvMSP- $1_{19}$ when comparing $P$. falciparum- and $P$. vivax-malaria patients.

Positive correlations were observed between antiPvMSP-1 19 IgG antibodies and IL-10 levels in P. vivaxmalaria patients $(p=0,0171 ; \mathrm{r}=0,7621)$; anti-PvMSP- $1_{19}$ IgM antibodies and IFN- $\gamma$ levels in $P$. falciparum-malaria patients $(p=0,0036 ; \mathrm{r}=0,7666)$ and; anti-PvMSP- $1_{19}$ IgE antibodies and TNF in both $P$. vivax- and $P$. falciparum-malaria patients ( $P$. vivax: $p=0,0432 ; \mathrm{r}=0,4081$; P. falciparum: $p=0,0455 ; \mathrm{r}=0,5856)$.

\section{Discussion}

In the present work, the profile of acquired cellular and antibody immune responses against PvMSP-1 19 was evaluated in individuals naturally exposed to $P$. vivax and $P$. falciparum infections in a malaria-endemic area in the north-western Amazon region of Brazil. 


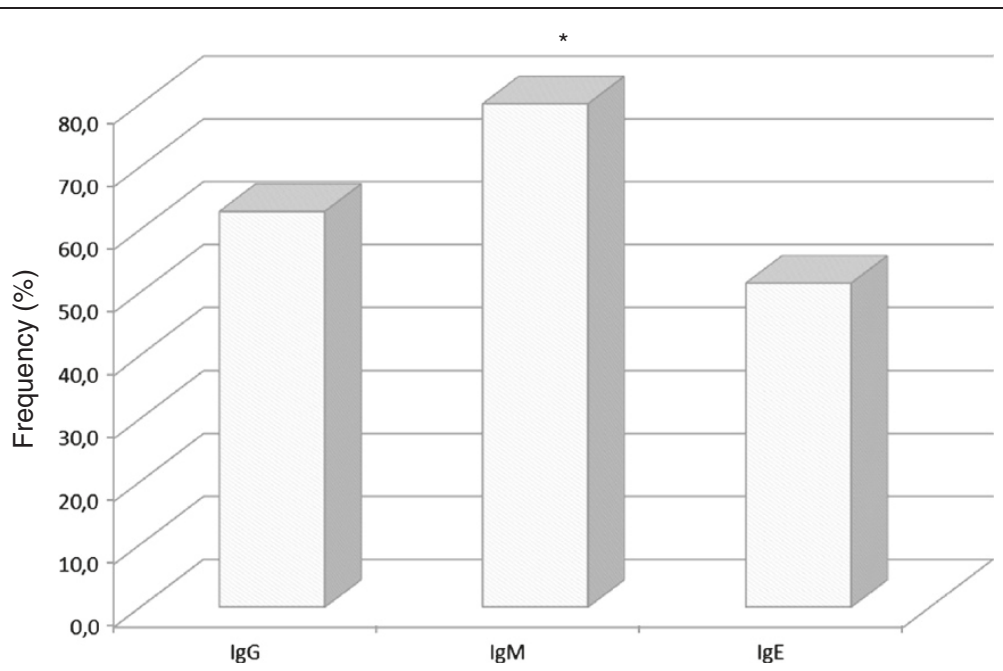

Figure 9 Analysis of antibodies in sera from malaria patients. Frequency of malaria patients $(n=35)$ with $\lg G$, lgM and lgE antibodies against PvMSP-1 $19 .^{*} p=0.02$, IgM versus lgE.

It is well known that suboptimal cryopreservation could result in a significant decrease of cell number and viability, causing alterations on the cellular phenotype and on the immune response to specific antigens. To avoid troublesome events, a protocol to successfully recovery PBMC after freezing and thawing was previously standardized [34]. Thus, in the present study, an important frequency of mononuclear cell viability after thawing was observed (around 78\%), regardless the individuals being infected or not. Because $75 \%$ PBMC viability is required for lymphocyte proliferation assays, representing the ability of cells to respond to the antigenic or mitogenic stimulation, independently of the nature or intensity of the stimulus [35], the cryopreservation procedure seems not have been a limiting factor in the present study.

The phenotypic analysis of ex-vivo PBMC revealed that $\mathrm{CD} 4^{+} \mathrm{T}$ cells were found more frequently than $\mathrm{CD}^{+}$and $\mathrm{CD}^{2} 0^{+}$cells, in both malaria and control individuals. In malaria individuals, a higher prevalence of activated $\mathrm{CD}^{+}$than $\mathrm{CD}^{+} \mathrm{T}$ cells was observed, in both ex-vivo and in $96 \mathrm{~h}$ culture in presence of PvMSP- $1_{19}$ and PSS1 antigen. It can be speculated that $\mathrm{CD} 4^{+} \mathrm{T}$ cells were the most stimulated cells due the nature of antigenic stimulus because $\mathrm{CD} 4^{+} \mathrm{T}$ cells are activated by the parasite in blood stage, while $\mathrm{CD}^{+} \mathrm{T}$ cells are most

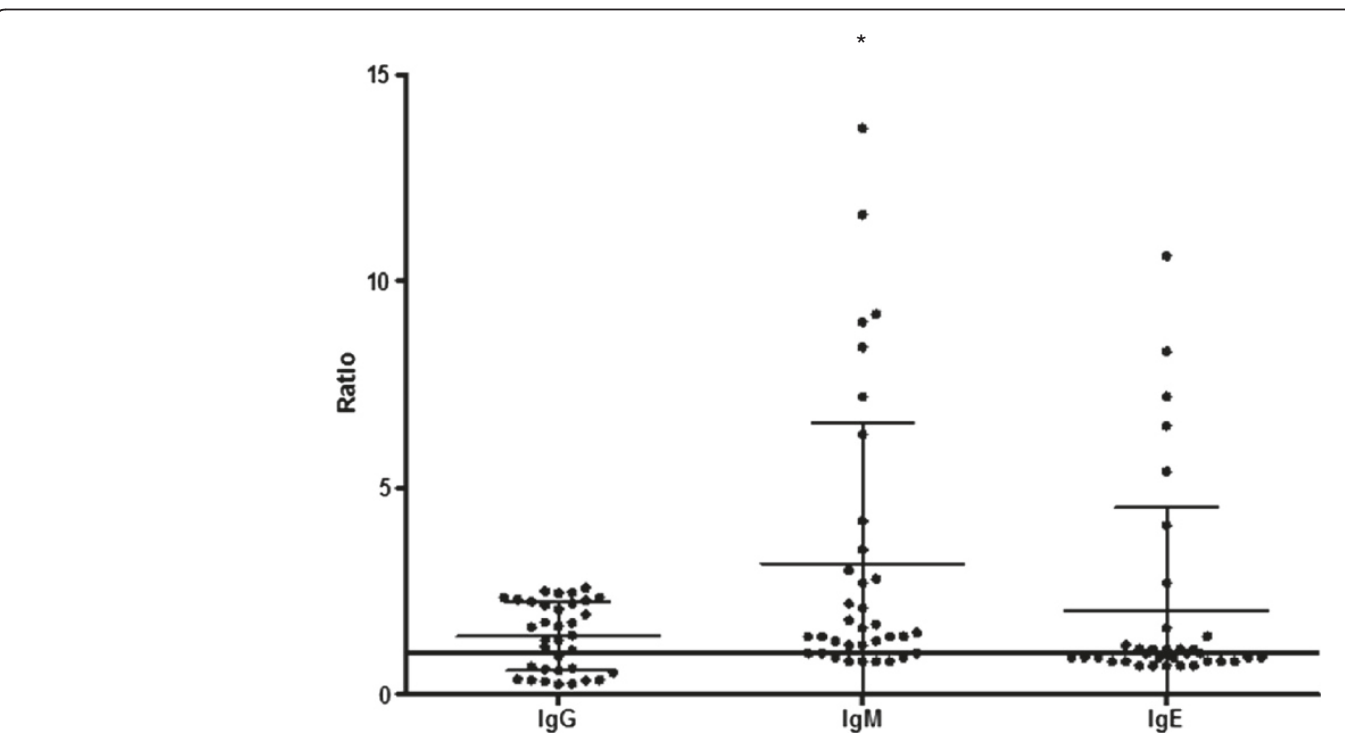

Figure 10 Analysis of IgG, IgM and IgE antibodies levels against PvMSP-1 ${ }_{19}$ in malaria patients. ${ }^{*} p=0.005$, IgM versus lgG. Lines represent mean with standard deviation. Continuous line represents cut off. 


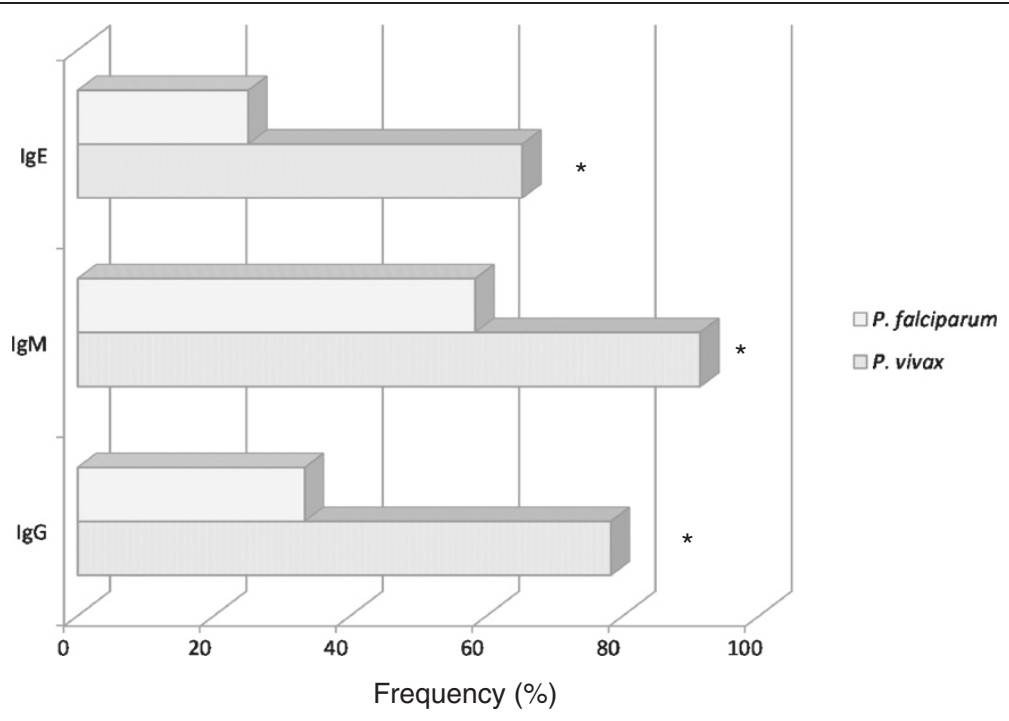

Figure 11 Prevalence of antibody responses against PvMSP-1 $1_{19}$ in malaria infected individuals. Frequency of $\operatorname{lgG}$, IgM and $\operatorname{lgE}$ antibodies in individuals with $P$. vivax or $P$. falciparum malaria. ${ }^{*} p=0.02$ for $\lg E, p=0.03$ for $\operatorname{lgM}$ and $\lg G, P$. vivax versus $P$. falciparum.

often activated during the hepatic stage of parasite life cycle [36].

Low proliferative responses in the presence of MSP- $1_{19}$ of P. falciparum and Plasmodium chabaudi chabaudi have already been demonstrated [37,38]. The results also showed a low proliferative response against PSS1 crude antigen or PvMSP- $1_{19}$ after $96 \mathrm{~h}$ culture. This low proliferative response may occur because the majority of activated cells undergo activated-induced cell death, an active cell suicide mechanism of widespread biological importance that constitutes the physiological response of normal cells to activation and is believed to control the number of antigen-stimulated cells during the immune response [39].

Anti-inflammatory cytokines are involved in a feedback mechanism to regulate the expression of pro-

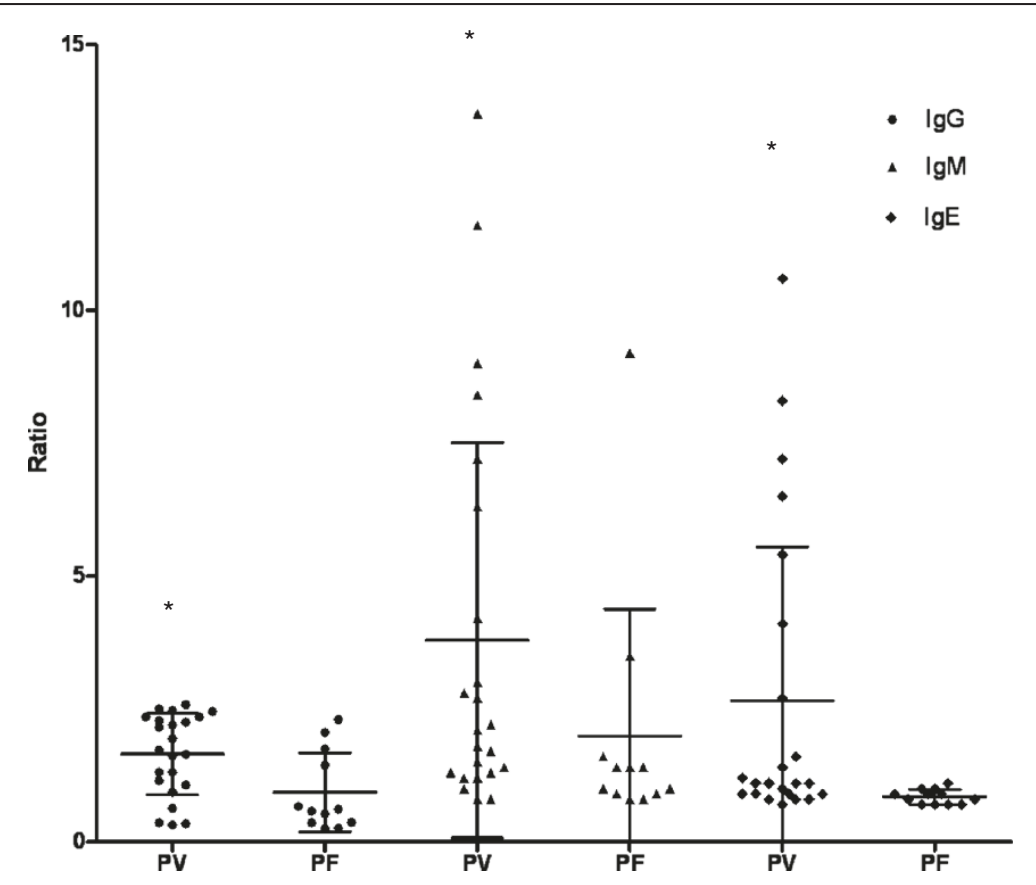

Figure 12 Levels of IgG, IgM and IgE antibodies. Analysis of antibodies levels against PVMSP-1 ${ }_{19}$ in $P$. vivax- or $P$. falciparum- infected individuals. * $p=0.01$ for $\operatorname{lgG}, p=0.04$ for $\lg M, p=0.003$ for $\lg E, P$. vivax versus $P$. falciparum. Lines represent mean with standard deviation. 


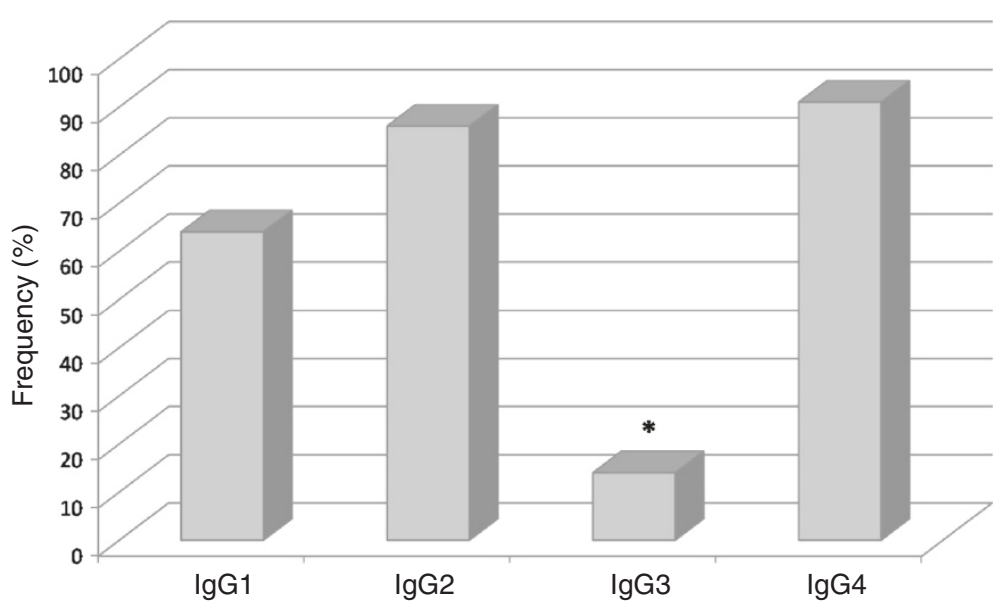

Figure 13 Frequency of IgG subclasses. Prevalence of $\lg G 1, \lg G 2, \lg G 3$ and $\lg G 4$ antibodies against PvMSP-1 $1_{19}$ in IgG-positive malaria patients $(\mathrm{n}=35) .{ }^{*} p=0.001, \lg \mathrm{G} 3$ versus $\lg \mathrm{G} 1 ; p<0.0001, \lg \mathrm{G} 3$ versus $\lg \mathrm{G} 2$ and $\lg \mathrm{G} 4$.

inflammatory cytokines, and prevent the pathological effects that may result from their continuous secretion. Previous in vitro studies have shown that IL-10 suppresses the expression of malaria parasite-induced production of TNF by PBMC [40]. In fact, in the present study, high plasmatic levels of IL-10 and low plasmatic levels of TNF were observed in malaria patients.

Parasite clearance seems to be related to IL-10 and IFN- $\gamma$ levels. Here, an intense secretion of IFN- $\gamma$ and IL10 as detected by dosage of plasmatic levels, were shown in malaria patients. However no correlation was found between parasitaemia and IFN- $\gamma$ or IL-10 levels. The high levels of IL-10 and IFN- $\gamma$ are in agreement with previous clinical reports that IL-10 is up-regulated in concern with IFN- $\gamma$ [41,42], suggesting that IL-10 may be up-regulated as a direct consequence of IFN- $\gamma$ production as part of homeostatic feedback mechanism to limit IFN- $\gamma$-mediated pathology, as is seen in murine malaria infections [43].

IL-10 levels were similar in $P$. vivax and $P$. falciparum infected individuals. However, besides plasmodial species, other factors, like the number of previous malaria infections, may influence the levels of this and other cytokines. In fact, a negative correlation between number

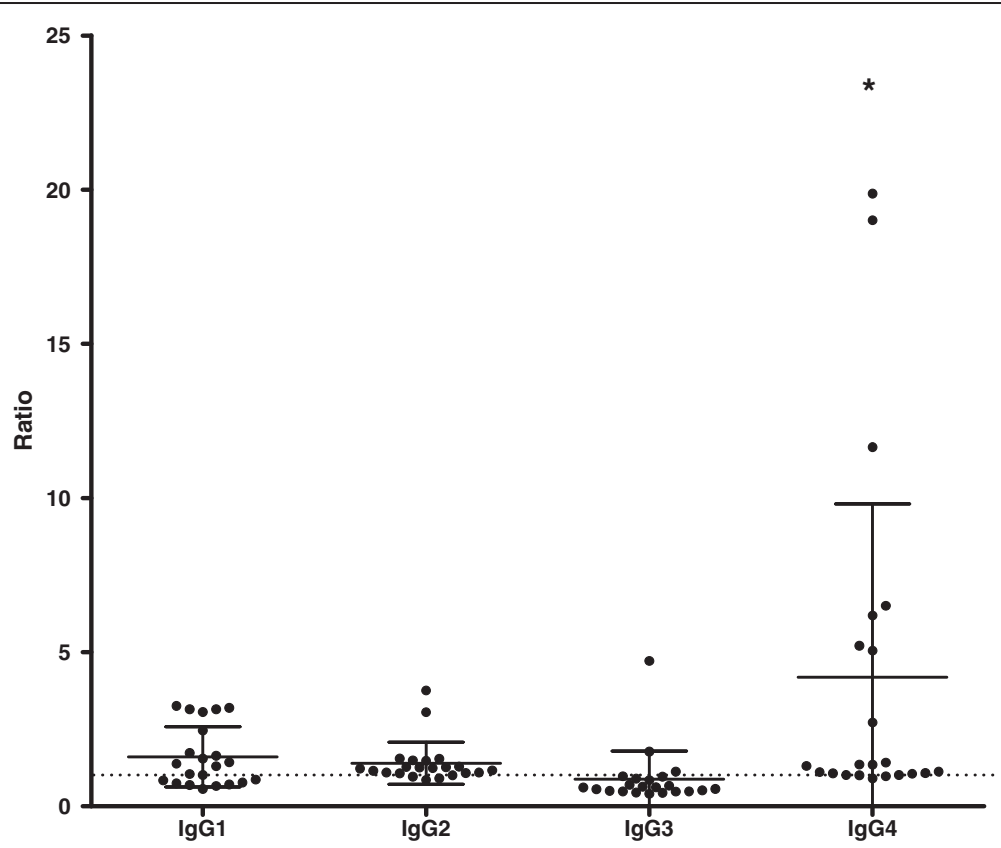

Figure 14 Levels of $\lg G 1, \lg \mathbf{2} 2$, IgG3 and IgG4 antibodies against PvMSP-1 ${ }_{19}$ in malaria patients. ${ }^{*} p=0.04, \operatorname{lgG} 4$ versuS $\lg \mathrm{G} 1 ; p=0.03$, $\operatorname{lgG} 4$ versus $\operatorname{lgG} 2 ; p=0.01$, lgG4 versus lgG3. Lines represent mean with standard deviation. Dotted line represents cut off. 
of previous malaria infections and IL-10 levels was found. In addition, previous studies have shown that an adaptive type 1 regulatory $\mathrm{CD}^{+}$cells have been identified as the main source of IL-10 in experimental murine infection with Plasmodium yoelii [44], while in $P$. chabaudi infections in mice, an activated effector $\mathrm{TH}_{1}$ cells were major IL-10 producers [45]. Understanding how these regulatory cells are induced could help to explain differences in IL-10 production in human malaria.

High production of TNF in malaria individuals is related to the development of severe malaria. In the present work, lower than expected plasmatic TNF levels (lower than those observed in control individuals) were detected in malaria patients. Interestingly, PvMSP- $1_{19^{-}}$ stimulated PBMCs from malaria patients showed higher TNF response than those recorded in both PSS1stimulated and non-stimulated PBMCs. The production of TNF in recall to PvMSP-1 19 may suggest a protective role of PvMSP-1 19 immune response because TNF has been related to parasite clearance.

A great majority of studied individuals presented antibodies against PvMSP-1 $1_{19}$, independently of the reported number of previous malaria attacks or the time of residence in a malaria-endemic area, indicating that this protein is immunogenic in natural conditions of exposure and seems to be independent of the time of exposure. The high immunogenicity of PvMSP-1 19 may be reflex of its limited polymorphism, because independent groups demonstrated that PvMSP-1 19 is conserved $[17,46,47]$. Another possible explanation is that PvMSP- $1_{19}$ is the single fragment that remains on the parasite surface during red cell invasion through glycosylphosphatidylinositol (GPI) anchor [13] and studies have described GPI as a potent agonists of toll-like receptors that may provide the adjuvant required for stronger immune responses [48].

Anti-PvMSP-1 19 antibodies were not detected in the sera of five individuals from malaria group (one with vivax and four with falciparum malaria). The absence of anti-PvMSP- $1_{19}$ antibodies could be related to immunosuppression observed in humans in malaria infection $[49,50]$, however, this hypothesis seems unlikely because these non-responders individuals presented antibodies against PSS1 crude antigen. Another possible explanation for the absence of these antibodies is that PvMSP$1_{19}$-specific $\mathrm{B}$ cells were present, although circulating antibodies titers were undetectable. Alternatively, the lack of PvMSP-1 19 antibody response may be due the genetic restriction of immune response that has been described to several plasmodial recombinant proteins and synthetic peptides [24,51-55]. However, in a recent study performed in the Brazilian Amazon region, no association between HLADRB1* and HLADQB1* allelic groups and the antibody response against PvMSP-1 19 was found [24].
Considering that different Plasmodium antigens in the same population as well as the same Plasmodium antigen in different populations can induce different antibody profiles, it was also evaluated the frequency and levels of IgG, IgM and IgE class and IgG subclass against PvMSP-1 19 . IgM antibodies were the most prevalent and the one with the highest levels. PvMSP-1 19 -induced IgG antibodies were predominantly of non-cytophilic subclasses. Different data have been reported for individuals living in other Brazilian-endemic areas with different levels of exposure where the PvMSP-1 19 -induced antibodies were predominantly of IgG1 subclass [20,23]. Differences in antibody profile may be due to transmission intensity. In fact, previous study has demonstrated that the levels of IgG1 and IgG3 specific antibodies were low among individuals with long-term exposure ( $\sim 19$ years) when compared to subjects less and sporadically exposed $(<1$ year) [20]. In this concern, one must emphasize that the individuals from malaria group claimed living in malaria endemic area for 19 years. Another additional hypothesis could be related to cytokine modulation of specific antibodies production because IL-10 has been reported to demonstrate both potentiating and inhibiting IgE and increasing IgG4 productions [56] as well as to be associated with IgM antibodies against $P$. vivax [57]. In addition, associations between polymorphism in cytokine genes and anti-plasmodial antibody response have been reported [53]. One other possibility could be the context of the response because co-infection with helminths is known to shift the $T h_{1}$ to the $\mathrm{Th}_{2}$ pattern of immune response modulating the IgG subclass expression. Independently of its origin, the differences between antibody profile reported in the present study and the aforementioned underline the importance of conducting immunoepidemiological studies in different malaria endemic areas where transmission intensities and human genetic background are different.

Associations between antibody responses with time of residence and/or number of previous episodes have been commonly reported to several malaria antigens $[52,58,59]$. However, in the present study, no association between levels of PvMSP-1 19 antibodies and number of previous malaria episodes was observed. This finding may reflect that people living for a longer period of time in the region may have acquired some degree of clinical immunity after experiencing a number of infections, therefore, reporting less episodes of clinical malaria in the more recent years. Interestingly, only the levels of IgE antibodies were inversely correlated with the number of previous malaria episodes. Thus, it can be supposed that higher levels of IgE antibodies may have an important role against clinical malaria. Similar results were already reported that shown that high levels of 
malaria specific IgE were associated with reduced risk for subsequent clinical malaria episodes [60].

In this study the frequency and the levels of IgG, IgM and IgE antibodies against PvMSP-1 $1_{19}$ were higher in individuals infected with $P$. vivax than $P$. falciparum or who had reported the last malaria episode due $P$. vivax. Similar results were reported elsewhere where sera from subjects who had had P. vivax in their last malaria clinical episode presented higher levels of antibodies when compared with those whose last malaria episode was due to P. falciparum [20].

The individuals infected with $P$. falciparum studied in this work reported previous infection with $P$. vivax. This may explain the recognition of $\mathrm{PvMSP}_{19}$ antigen by antibodies from individuals infected with $P$. falciparum. However, the similarity between PfMSP1 and PvMSP1 antigens may also explain, at least in part, the recognition of PvMSP1 by patients infected with P. falciparum, although a recent study has shown that sera from immunized mice with PfMSP1 19 or PvMSP1 19 failed to crossreact with heterologous antigen [61].

In conclusion, the results presented here shows that PvMSP- $1_{19}$ was able to induce a high cellular activation leading to production of TNF, emphasizing the high immunogenicity of PvMSP- $1_{19}$ in naturally exposed individuals and therefore its potential as a malaria vaccine candidate.

\section{Competing interests}

The authors declare that they have no competing interests.

\section{Authors' contributions}

EKPR designed the study, carried out the experiments, performed the statistical analysis and drafted the manuscript; PRRT, VEV and LRPR participated in its design, carried out the experiments and reviewed the manuscript; MMR and ISS produced and provided the PVMSP-1 19; JMS enabled and facilitated the performance of experiments in Paragominas; CTDR reviewed the manuscript and MFFC conceived the study, participated in its design and coordination and reviewed the manuscript. All authors have read and approved the final manuscript.

\section{Acknowledgements}

We are grateful to all patients that agreed to participate in this study for their cooperation and generous donation of blood, which made this study possible. This work was supported by Fundação de Amparo à Pesquisa do Estado do Rio de Janeiro (FAPERJ, Brazil), Conselho Nacional de Desenvolvimento Científico e Tecnológico (CNPq, Brazil), Instituto Oswaldo Cruz (FIOCRUZ, Brazil). MFFC and CTDR are recipients of a Research Productivity Fellowship from CNPq and receive a grant from FAPERJ as "Cientistas do Nosso Estado".

\section{Author details}

'Laboratório de Pesquisas em Malária, Instituto Oswaldo Cruz, Fiocruz, Avenida Brasil 4365, Manguinhos, Rio de Janeiro, RJ, BrazilCEP: 21040-900. ${ }^{2}$ Centro de Pesquisa, Diagnóstico e Treinamento em Malária (CPD-Mal), Fiocruz, Reference Center for Malaria in the Extra-Amazonian Region for the Secretary for Health Surveillance from the Ministry of Health, Rio de Janeiro, RJ, Brazil. 'Laboratório de Biologia Molecular e Doenças Endêmicas, Instituto Oswaldo Cruz, Fiocruz, Rio de Janeiro, RJ, Brazil. ${ }^{4}$ Departamento de Análises Clínicas e Toxicológicas, Universidade de São Paulo, São Paulo, Brazil. ${ }^{5}$ Departamento de Microbiologia, Imunologia e Parasitologia, Universidade Federal de São Paulo, São Paulo, Brazil. ${ }^{6}$ Programa de Ensaios Clínicos em Malária - Instituto Evandro Chagas, SVS, Belém, Brazil.
Received: 23 July 2013 Accepted: 10 September 2013

Published: 16 September 2013

\section{References}

1. WHO: World Malaria Report 2012. Geneva: World Health Organization; 2012 [http://www.who.int/malaria/publications/world_malaria_report_2012/en/]

2. Barcus MJ, Basri H, Picarima H, Manyakori C, Sekartuti, Elyazar I, Bangs MJ, Maguire JD, Baird JK: Demographic risk factors for severe and fatal vivax and falciparum malaria among hospital admissions in northeastern Indonesian Papua. Am J Trop Med Hyg 2007, 77:984-991.

3. Tjitra E, Anstey NM, Sugiarto P, Warikar N, Kenangalem E, Karyana M, Lampah DA, Price RN: Multidrug-resistant Plasmodium vivax associated with severe and fatal malaria: a prospective study in Papua, Indonesia. PLoS Med 2008, 5:e128.

4. Genton B, D'Acremont V, Rare L, Baea K, Reeder JC, Alpers MP, Muller I: Plasmodium vivax and mixed infections are associated with severe malaria in children: a prospective cohort study from Papua New Guinea. PLoS Med 2008, 5:e127.

5. Kochar DK, Das A, Kochar SK, Saxena V, Sirohi P, Garg S, Kochar A, Khatri MP, Gupta V: Severe Plasmodium vivax malaria: a report on serial cases from Bikaner in northwestern India. Am J Trop Med Hyg 2009, 80:194-198.

6. Anstey NM, Russell B, Yeo TW, Price RN: The pathophysiology of vivax malaria. Trends Parasitol 2009, 25:220-227.

7. Alexandre MA, Ferreira CO, Siqueira AM, Magalhães BL, Mourão MP, Lacerda MV, Alecrim MG: Severe Plasmodium vivax malaria, Brazilian Amazon. Emerg Infect Dis 2010, 16:1611-1614.

8. Manning L, Laman M, Law I, Bona C, Aipit S, Teine D, Warrell J, RosanasUrgell A, Lin E, Kiniboro B, Vince J, Hwaiwhanje I, Karunajeewa H, Michon P, Siba P, Mueller I, Davis TM: Features and prognosis of severe malaria caused by Plasmodium falciparum Plasmodium vivax and mixed Plasmodium species in Papua New Guinean children. PLoS One 2011, 6:e29203.

9. Yadav D, Chandra J, Aneja S, Kumar V, Kumar P, Dutta AK: Changing profile of severe malaria in north Indian children. Indian J Pediatr 2012, 79:483-487.

10. Lacerda MV, Mourão MP, Alexandre MA, Siqueira AM, Magalhães BM, Martinez-Espinosa FE, Filho FS, Brasil P, Ventura AM, Tada MS, Couto VS, Silva AR, Silva RS, Alecrim MG: Understanding the clinical spectrum of complicated Plasmodium vivax malaria: a systematic review on the contributions of the Brazilian literature. Malar J 2012, 11:12.

11. SVS: Boletim Epidemiológico da Malária. ; 2012. [http://portal.saude.gov.br/ portal/arquivos/pdf/boletim_malaria_2010_2011.pdf]

12. Cruz-Gallardo I, Diaz-Moreno I, Diaz-Quintana A, Donaire A, VelazquezCampoy A, Curd RD, Rangachari K, Birdsall B, Ramos A, Holder AA, De la Rosa MA: Antimalarial activity of cupredoxins: the interaction of Plasmodium merozoite surface protein $1_{19}\left(\mathrm{MSP}-1_{19}\right)$ and Rusticyanin. J Biol Chem 2013, 288:20896-20907.

13. Blackman MJ, Heidrich HG, Donachie S, McBride JS, Holder AA: A single fragment of a malaria merozoite surface protein remains on the parasite during red cell invasion and is the target of invasion-inhibiting antibodies. J Exp Med 1990, 172:379-382.

14. Holder AA, Blackman MJ, Burghaus PA, Chappel JA, Ling IT, McCallumDeighton N, Shai S: A malaria merozoite surface protein (MSP1)-structure, processing and function. Mem Inst Oswaldo Cruz 1992, 87:37-42.

15. Gerold P, Schofield L, Blackman MJ, Holder AA, Schwarz RT: Structural analysis of the glycosyl-phosphatidylinositol membrane anchor of the merozoite surface proteins- 1 and -2 of Plasmodium falciparum. Mol Biochem Parasitol 1996, 75:131-143.

16. Soares IS, Levitus G, Souza JM, Del Portillo HA, Rodrigues MM: Acquired immune responses to the $\mathrm{N}$ - and $\mathrm{C}$-terminal regions of Plasmodium vivax merozoite surface protein 1 in individuals exposed to malaria. Infect Immun 1997, 65:1606-1614

17. Soares IS, Oliveira SG, Souza JM, Rodrigues MM: Antibody response to the $\mathrm{N}$ and C-terminal regions of the Plasmodium vivax merozoite surface protein 1 in individuals living in an area of exclusive transmission of $P$. vivax malaria in the north of Brazil. Acta Trop 1999, 72:13-24.

18. Park JW, Moon SH, Yeom JS, Lim KJ, Sohn MJ, Jung WC, Cho YJ, Jeon KW, Ju W, Ki CS, Oh MD, Choe K: Naturally acquired antibody responses to the C-terminal region of merozoite surface protein 1 of Plasmodium vivax in Korea. Clin Diagn Lab Immunol 2001, 8:14-20. 
19. Rodrigues MH, Cunha MG, Machado RL, Ferreira OC Jr, Rodrigues MM, Soares IS: Serological detection of Plasmodium vivax malaria using recombinant proteins corresponding to the $19-\mathrm{kDa}$ C-terminal region of the merozoite surface protein-1. Malar J 2003, 2:39.

20. Morais CG, Soares IS, Carvalho LH, Fontes CJ, Krettli AU, Braga EM: IgG isotype to C-terminal $19 \mathrm{kDa}$ of Plasmodium vivax merozoite surface protein 1 among subjects with different levels of exposure to malaria in Brazil. Parasitol Res 2005, 95:420-426.

21. Wickramarachchi T, Illeperuma RJ, Perera L, Bandara S, Holm I, Longacre S, Handunnetti SM, Udagama-Randeniya PV: Comparison of naturally acquired antibody responses against the C-terminal processing products of Plasmodium vivax merozoite surface protein-1 under low transmission and unstable malaria conditions in Sri Lanka. Int J Parasitol 2007, 37:199-208

22. Barbedo MB, Ricci R, Jimenez MC, Cunha MG, Yazdani SS, Chitnis CE, Rodrigues MM, Soares IS: Comparative recognition by human IgG antibodies of recombinant proteins representing three asexual erythrocytic stage vaccine candidates of Plasmodium vivax. Mem Inst Oswaldo Cruz 2007, 102:335-339.

23. Mourão LC, Morais CG, Bueno LL, Jimenez MC, Soares IS, Fontes CJ, Guimarães Lacerda MV, Xavier MS, Barnwell JW, Galinski MR, Braga EM: Naturally acquired antibodies to Plasmodium vivax blood-stage vaccine candidates (PvMSP-1 19 and PvMSP-3a $a_{359-798}$ and their relationship with hematological features in malaria patients from the Brazilian Amazon. Microbes Infect 2012, 14:730-739.

24. Lima-Junior JC, Rodrigues-da-Silva RN, Banic DM, Jiang J, Singh B, FabrícioSilva GM, Porto LC, Meyer EV, Moreno A, Rodrigues MM, Barnwell JW, Galinski MR, de Oliveira-Ferreira J: Influence of HLA-DRB1 and HLA-DQB1 alleles on IgG antibody response to the P. vivax MSP-1, MSP-3a and MSP-9 in individuals from Brazilian endemic area. PLoS One 2012. 7:e36419.

25. Yang C, Collins WE, Sullivan JS, Kaslow DC, Xiao L, Lal AA: Partial protection against Plasmodium vivax blood-stage infection in Saimiri monkeys by immunization with a recombinant C-terminal fragment of merozoite surface protein 1 in block copolymer adjuvant. Infect Immun 1999, 67:342-349

26. Ling IT, Ogun SA, Holder AA: Immunization against malaria with a recombinant protein. Parasite Immunol 1994, 16:63-67.

27. Daly TM, Long CA: Humoral response to a carboxyl-terminal region of the merozoite surface protein-1 plays a predominant role in controlling blood-stage infection in rodent malaria. J Immunol 1995, 155:236-243.

28. Holder AA, Guevara Patiño JA, Uthaipibull C, Syed SE, Ling IT, Scott-Finnigan T, Blackman MJ: Merozoite surface protein 1, immune evasion, and vaccines against asexual blood stage malaria. Parassitologia 1999, 41:409-414.

29. Hirunpetcharat C, Tian JH, Kaslow DC, van Rooijen N, Kumar S, Berzofsky JA, Miller LH, Good MF: Complete protective immunity induced in mice by immunization with the 19-kilodalton carboxyl-terminal fragment of the merozoite surface protein-1 (MSP-1 ${ }_{19}$ ) of Plasmodium yoelii expressed in Saccharomyces cerevisiae: correlation of protection with antigen-specific antibody titer, but not with effector CD4+ T cells. J Immunol 1997, 159:3400-3411.

30. Hirunpetcharat C, Stanisic D, Liu XQ, Vadolas J, Strugnell RA, Lee R, Miller LH, Kaslow DC, Good MF: Intranasal immunization with yeast-expressed 19 kD carboxyl-terminal fragment of Plasmodium yoelii merozoite surface protein-1 (yMSP-1 19 ) induces protective immunity to blood stage malaria infection in mice. Parasite Immunol 1998, 20:413-420.

31. Ichino $Y$, Ishikawa T: Effects of cryopreservation on human lymphocyte functions: comparison of programmed freezing method by a direct control system with a mechanical freezing method. $J$ Immunol Methods 1985, 77:283-290.

32. Schmid I, Uittenbogaart $\mathrm{CH}$, Keld B, Giorgi JV: A rapid method for measuring apoptosis and dual-color immunofluorescence by single laser flow cytometry. J Immunol Methods 1994, 170:145-157.

33. Trager $W$, Jensen JB: Human malaria parasites in continuous culture. Science 1976, 193:673-675.

34. Riccio EKP, Neves-Júnior I, Riccio LRP, Banic DM, Daniel-Ribeiro CT, Ferreirada-Cuz MF: Cryopreservation of peripheral blood mononuclear cells does not affect the levels of spontaneous apoptosis after $24 \mathrm{~h}$ culture. Cryobiology 2002, 45:127-134
35. Weinberg A, Song LY, Wilkening C, Sevin A, Blais B, Louzao R, Stein D, Defechereux P, Durand D, Riedel E, Raftery N, Jesser R, Brown B, Keller MF, Dickover R, McFarland E, Fenton T: Optimization and limitations of use of cryopreserved peripheral blood mononuclear cells for functional and phenotypic T-cell characterization. Clin Vaccine Immunol 2009, $16: 1176-1186$

36. Torre D, Speranza F, Giola M, Matteelli A, Tambini R, Biondi G: Role of Th1 and Th2 cytokines in immune response to uncomplicated Plasmodium falciparum malaria. Clin Diagn Lab Immunol 2002, 9:348-351.

37. Quin SJ, Seixas EM, Cross CA, Berg M, Lindo V, Stockinger B, Langhorne J: Low CD4(+) T cell responses to the C-terminal region of the malaria merozoite surface protein-1 may be attributed to processing within distinct MHC class II pathways. Eur J Immunol 2001, 31:72-81.

38. Mukherjee P, Devi YS, Chauhan VS: Blood stage malaria antigens induce different activation-induced cell death programs in splenic CD4 + T cells. Parasite Immunol 2008, 30:497-514.

39. Green DR, Droin N, Pinkoski M: Activation-induced cell death in T cells. Immunol Rev 2003, 193:70-81.

40. Ho M, Schollaardt T, Snape S, Looareesuwan S, Suntharasamai P, White NJ: Endogenous interleukin-10 modulates proinflammatory response in Plasmodium falciparum malaria. J Infect Dis 1998, 178:520-525.

41. Day NP, Hien TT, Schollaardt T, Loc PP, Chuong LV, Chau TT, Mai NT, Phu $\mathrm{NH}$, Sinh DX, White NJ, Ho M: The prognostic and pathophysiologic role of pro- and antiinflammatory cytokines in severe malaria. J Infect Dis 1999, 180:1288-1297

42. Walther M, Woodruff J, Edele F, Jeffries D, Tongren JE, King E, Andrews L, Bejon P, Gilbert SC, De Souza JB, Sinden R, Hill AV, Riley EM: Innate immune responses to human malaria: heterogeneous cytokine responses to blood-stage Plasmodium falciparum correlate with parasitological and clinical outcomes. J Immunol 2006, 177:5736-5745.

43. Li C, Sanni LA, Omer F, Riley E, Langhorne J: Pathology of Plasmodium chabaudi chabaudi infection and mortality in interleukin-10-deficient mice are ameliorated by anti-tumor necrosis factor alpha and exacerbated by anti-transforming growth factor beta antibodies. Infect Immun 2003, 71:4850-4856.

44. Couper KN, Blount DG, Riley EM: IL-10: the master regulator of immunity to infection. J Immunol 2008, 180:5771-5777.

45. Rosario AP F d, Langhorne J: T cell-derived IL-10 and its impact on the regulation of host responses during malaria. Int J Parasitol 2012, 42:549-555.

46. O'Donnell RA, Saul A, Cowman AF, Crabb BS: Functional conservation of the malaria vaccine antigen MSP-119across distantly related Plasmodium species. Nat Med 2000, 6:91-95.

47. Putaporntip C, Jongwutiwes S, Sakihama N, Ferreira MU, Kho WG, Kaneko A, Kanbara H, Hattori T, Tanabe K: Mosaic organization and heterogeneity in frequency of allelic recombination of the Plasmodium vivax merozoite surface protein-1 locus. Proc Natl Acad Sci USA 2002, 99:16348-16353.

48. Gowda DC: TLR-mediated cell signaling by malaria GPIs. Trends Parasitol 2007, 23:596-604.

49. McGregor IA, Barr M: Antibody response to tetanus toxoide inoculation in malarious and non-malarious Gambian children. Trans $R$ Soc Trop Med Hyg 1962, 56:364-367.

50. Ho M, Webster HK, Looareesuwan S, Supanaranond W, Phillips RE, Chanthavanich P, Warrell DA: Antigen-specific immunosuppression in human malaria due to Plasmodium falciparum. J Infect Dis 1986, 3:763-771.

51. Oliveira-Ferreira J, Pratt-Riccio LR, Arruda M, Santos F, Ribeiro CT, Goldberg AC, Banic DM: HLA class II and antibody responses to circumsporozoite protein repeats of $P$. vivax (VK210, VK247 and $P$. vivax-like) in individuals naturally exposed to malaria. Acta Trop 2004, 92:63-69.

52. Pratt-Riccio LR, Lima-Junior JC, Carvalho LJ, Theisen M, Espindola-Mendes EC, Santos F, Oliveira-Ferreira J, Goldberg AC, Daniel-Ribeiro CT, Banic DM: Antibody response profiles induced by Plasmodium falciparum glutamate-rich protein in naturally exposed individuals from a brazilian area endemic for malaria. Am J Trop Med Hyg 2005, 73:1096-1103.

53. Carpenter D, Abushama H, Bereczky S, Färnert A, Rooth I, Troye-Blomberg M, Quinnell RJ, Shaw MA: Immunogenetic control of antibody responsiveness in a malaria endemic area. Hum Immunol 2007, 68:165-169.

54. Storti-Melo LM, da Costa DR, Souza-Neiras WC, Cassiano GC, Couto VS, Póvoa MM, Soares Ida S, de Carvalho LH, Arevalo-Herrera M, Herrera S, 
Rossit AR, Cordeiro JA, de Mattos LC, Machado RL: Influence of HLA-DRB-1 alleles on the production of antibody against CSP, MSP-1, AMA-1, and DBP in Brazilian individuals naturally infected with Plasmodium vivax. Acta Trop 2012, 121:152-155.

55. Sabbagh A, Courtin D, Milet J, Massaro JD, Castelli EC, Migot-Nabias F, Favier B, Rouas-Freiss N, Moreau P, Garcia A, Donadi EA: Association of HLA-G 3' untranslated region polymorphisms with antibody response against Plasmodium falciparum antigens: preliminary results. Tissue Antigens 2013, 82:53-58.

56. Jeannin $P$, Lecoanet $S$, Delneste $Y$, Gauchat JF, Bonnefoy JY: IgE versus IgG4 production can be differentially regulated by IL-10. J Immunol 1998, 160:3555-3561.

57. Fernandes AA, Carvalho LJ, Zanini GM, Ventura AM, Souza JM, Cotias PM Silva-Filho IL, Daniel-Ribeiro CT: Similar cytokine responses and degrees of anemia in patients with Plasmodium falciparum and Plasmodium vivax infections in the Brazilian Amazon region. Clin Vaccine Immunol 2008, 15:650-658.

58. Cerávolo IP, Bruña-Romero O, Braga EM, Fontes CJ, Brito CF, Souza JM, Krettli AU, Adams JH, Carvalho LH: Anti-Plasmodium vivax duffy binding protein antibodies measure exposure to malaria in the Brazilian Amazon. Am J Trop Med Hyg 2005, 72:675-681.

59. Tran TM, Oliveira-Ferreira J, Moreno A, Santos F, Yazdani SS, Chitnis CE, Altman JD, Meyer EV, Barnwell JW, Galinski MR: Comparison of IgG reactivities to Plasmodium vivax merozoite invasion antigens in a Brazilian Amazon population. Am J Trop Med Hyg 2005, 73:244-255

60. Bereczky S, Montgomery SM, Troye-Blomberg M, Rooth I, Shaw MA, Färnert A: Elevated anti-malarial lgE in asymptomatic individuals is associated with reduced risk for subsequent clinical malaria. Int J Parasitol 2004 34:935-942.

61. Mehrizi AA, Zakeri S, Rafati S, Salmanian AH, Djadid ND: Immune responses elicited by co-immunization of Plasmodium vivax and P. falciparum MSP1 using prime-boost immunization strategies. Parasite Immunol 2011, 33:594-608.

doi:10.1186/1475-2875-12-326

Cite this article as: Riccio et al:: Cellular and humoral immune responses against the Plasmodium vivax MSP- $1_{19}$ malaria vaccine candidate in individuals living in an endemic area in north-eastern Amazon region of Brazil. Malaria Journal 2013 12:326.

\section{Submit your next manuscript to BioMed Central and take full advantage of:}

- Convenient online submission

- Thorough peer review

- No space constraints or color figure charges

- Immediate publication on acceptance

- Inclusion in PubMed, CAS, Scopus and Google Scholar

- Research which is freely available for redistribution 